\title{
INTEGRATING MONEY INTO REGIONAL MODELS OF LEADING INDICATORS
}

\author{
Paul J. Kozlowski*
}

\begin{abstract}
Given the role of monetary changes in explaining business cycles, a challenge for regional analysts is to integrate monetary processes into leading indicator models. This paper examines economic processes imbedded in regional models and analyzes changes in forecasting performance when a national monetary indicator is integrated into these models. Performance of the models, with and without the monetary variable, is examined with respect to turning points, volatility, false signals, and quantitative forecasts. The results show that integrating a national monetary indicator into the regional models of leading indicators is conceptually sound as well as empirically promising, and may contribute to the information content imbedded in this class of models.
\end{abstract}

\section{INTRODUCTION}

This paper reports observations on a class of forecasting models referred to as regional composite indexes of leading indicators. Individual leading economic indicators are used extensively to forecast shifts in the cyclical phase of national as well as regional economies. Models which combine individual indicators into indexes have been developed and are now used in many states and metropolitan areas. While the primary forecasting objective seems to have been met by early signals emanating from these indexes, their explanatory power is less certain because of the rather narrow set of economic processes imbedded in the models. Given the role of monetary changes in explaining business cycles, a challenge for regional analysts is to integrate monetary processes into leading indicator models. Integration may improve not only the empirical performance of the models themselves, but also the economic interpretation of cyclical movements in regions.

In order to assess how these regional models are progressing, this paper examines the processes imbedded in the models and analyzes changes in forecasting performance when a national monetary indicator is integrated into some of the models. Section I summarizes the theoretical underpinnings for integrating monetary factors into regional models. Section II examines the component structure of a large group of models. Section III presents results of empirical tests of forecast performance using reconstructed models with a national monetary indicator added.

\footnotetext{
*Professor of Business Economics, College of Business Administration, The University of Toledo. The author would like to thank anonymous referees for helpful comments.
} 


\section{MONEY AND THE ECONOMY}

No unified theory of the business cycle exists, but a wide variety of theoretical explanations impart some influence to monetary phenomena. There is a long and rich tradition of theorizing, as well as an energetic controversy over the role of money in accounting for real cyclical movements in an economy. This controversy centers around whether monetary factors are originating impulses or simply parts of a propagation mechanism that perpetuates cumulative cyclical swings. In short, monetary changes may contribute to a real propagation of cyclical behavior; but conversely, real shocks may be spread throughout the economy via a monetary propagation mechanism. Recent summaries on the evolution of money and monetary phenomena in business cycle theories and analyses are provided by Abdullah and Rangazas (1988), Carlstrom and Gamber (1989), Friedman (1986), Meltzer (1986), and Zarnowitz (1985).

Despite controversy over the role of money, business cycle analysts and forecasters continue to give monetary factors a key role in explaining short-run cyclical changes. This preference is reflected in the following statement:

The widely anticipated economic slowdown in the closing quarter of 1989 was severe enough to hold the growth of real GNP to an estimated 0.9 percent at an annual rate. The prime source of the slowdown was the Fed's anti-inflation, tight-money policy which lasted from the spring of ' 88 to the summer of ' 89 .

Hymans, Crary, and Wolfe (1990)

The concensus among economists regarding money and real economic activity is summarized by Carlstrom and Gamber $(1989,30)$ :

Most economists currently favor the interpretation that money causes output. They believe that some nominal rigidities, or price/wage sluggishness, allow changes in nominal variables, like money, to have real impacts.

Two issues are important for regional analysis and forecasting. First is the persistence of national business cycles and the wide variation in cyclical sensitivity among regions. Second is the role that monetary conditions may play in a regional business cycle setting.

The second issue centers on the role of money in explaining regional business cycles. Research by Beare (1976) is worth noting. Using a reduced-form specification, he linked the national money stock to activity in regions as given in 
Equation (1). Money may influence regional expenditures through several channels supplemented by multiplier-accelerator interactions.

$$
\begin{aligned}
& \mathrm{E}_{\mathrm{i}}=\mathrm{a}+\mathrm{bM}+\mathrm{cA}_{\mathrm{i}} \\
& \text { where } \mathrm{E}=\text { expenditure on products of the ith region; } \\
& \mathrm{M}=\text { national money supply; } \\
& \mathrm{A}=\text { autonomous expenditures on the products of a region. }
\end{aligned}
$$

Beare's empirical tests for Canadian provinces were carried out with distributed lag estimates for each province, using nominal and real values of income as specified in Equation 2:

$$
\begin{aligned}
& Y_{t}=b_{0}+b_{1} M(t, t-i)+b_{2} Y_{f}(t, t-j) \\
& \text { where } Y=\text { personal income before taxes; } \\
& M=\text { national money supply; } \\
& Y_{f}=\text { total net income of farm operators from farming operations. }
\end{aligned}
$$

The results showed that money was an important explanatory variable, with $b_{1}>b_{2}$ in nearly all cases. Furthermore, money led personal income for up to eight months. This latter result is significant if money is to contribute to forecasting cyclical changes in leading indicator models.

Additionally, research by Cohen and Maeshiro (1977) and Roberts and Fishkind (1979) demonstrated the importance of money in a regional context. The latter showed that explicit specification of a region's financial sector contributes to improved forecasting performance for a state econometric model. The former demonstrated that money exerts a significant influence on gross state product with some leads for a monetary variable. Regional empirical research therefore points toward analysis of monetary factors; and as Roberts and Fishkind $(1979,17)$ suggest: " . . by ignoring monetary and financial variables, an important set of linkages between a region's economy and the national economy is unexplored."

This may be the case currently for regional models of leading indicators. Moreover, in a business cycle policy context, regional stabilization activities may help reduce the amplitude of cyclical swings. Allen (1982) demonstrated that timing appears to be critical to the success of such policies. Therefore, it is worth examining whether models whose primary function is to provide timing informa- 
tion exhibit improved forecasting performance when monetary processes are integrated with the real processes that tend to dominate this class of models.

\section{COMPONENT STRUCTURE}

An explanation of the performance of a leading indicator model resides in the behavior of its components. Table 1 shows that regional models differ greatly in terms of components which represent a variety of processes: RLMI-regional labor market information; RINV-regional investment activities; RFIN-regional financial activities; ROTH-other regional processes; NDD-national demand conditions; NINV-national investment activities; NFIN-national financial activities; and NOTH-other national processes.

TABLE 1

Component Structure of Leading Indicator Models

\begin{tabular}{|c|c|c|c|c|c|c|c|c|c|c|}
\hline & & \multirow{2}{*}{$\begin{array}{c}\begin{array}{c}\text { Number } \\
\text { of } \\
\text { components }\end{array} \\
\end{array}$} & \multicolumn{4}{|c|}{ Regional Process } & \multicolumn{4}{|c|}{ National Process } \\
\hline & & & RLMI & RINV & RFIN & ROTH & NDD & NINV & NFIN & NOTH \\
\hline 1. & Akron & 5 & 2 & 1 & 0 & 0 & 1 & 0 & 0 & 1 \\
\hline 2. & Arizona & 10 & 3 & 2 & 0 & 4 & 0 & 0 & 1 & 0 \\
\hline 3. & Battle Creek & 7 & 2 & 1 & 0 & 0 & 4 & 0 & 0 & 0 \\
\hline 4. & Canton & 5 & 2 & $i$ & 0 & 0 & 1 & 0 & 0 & 1 \\
\hline 5. & Cincinnati & 5 & 2 & 1 & 0 & 0 & 1 & 0 & 0 & 1 \\
\hline 6. & Cleveland & 5 & 2 & $i$ & 0 & 0 & $i$ & 0 & 0 & 1 \\
\hline 7. & Colorado & 8 & 2 & 3 & 1 & 0 & 2 & 0 & 0 & 0 \\
\hline 8. & Columbus & 5 & 2 & 1 & 0 & 0 & 1 & 0 & 0 & 1 \\
\hline 9. & Dayton & 5 & 2 & $i$ & 0 & 0 & 1 & 0 & 0 & 1 \\
\hline 10. & Detroit & 6 & 2 & 1 & 1 & 0 & 1 & 1 & 0 & 0 \\
\hline 11. & Florida & 7 & 4 & 1 & 0 & 1 & 0 & 0 & 0 & 1 \\
\hline 12. & Font Wayne & 4 & 1 & $i$ & 1 & 0 & 0 & 0 & 1 & 0 \\
\hline 13. & Georgia & 6 & 2 & 2 & 1 & 1 & 0 & 0 & 0 & 0 \\
\hline 14. & Grand Rapids & 7 & 2 & 1 & 0 & 0 & 4 & 0 & 0 & 0 \\
\hline 15. & Idaho & 6 & 5 & 1 & 0 & 0 & 0 & 0 & 0 & 0 \\
\hline 16. & Illinois & 7 & 3 & 1 & 0 & 3 & 0 & 0 & 0 & 0 \\
\hline 17. & Kalamazoo & 7 & 2 & 1 & 0 & 0 & 4 & 0 & 0 & 0 \\
\hline 18. & Kentucky & 11 & 9 & 0 & 0 & 2 & 0 & 0 & 0 & 0 \\
\hline 19. & Memphis & 4 & 3 & 0 & 0 & 1 & 0 & 0 & 0 & 0 \\
\hline 20. & Michigan & 7 & 2 & 1 & 0 & 0 & 4 & 0 & 0 & 0 \\
\hline 21. & Muskegan & 7 & 2 & 1 & 0 & 0 & 4 & 0 & 0 & 0 \\
\hline 22. & Nebraska & 5 & 2 & $i$ & 0 & 1 & 0 & 0 & 1 & 0 \\
\hline 23. & Ohio (OBES) & 5 & 2 & $i$ & 0 & 0 & 1 & 0 & 0 & 1 \\
\hline 24. & Ohio (ODoD) & 5 & 2 & 2 & 1 & 0 & 0 & 0 & 0 & 0 \\
\hline 25. & Pennsylvania & 3 & 2 & 1 & 0 & 0 & 0 & 0 & 0 & 0 \\
\hline 26. & Philadelphia & 4 & 1 & $i$ & 0 & 1 & 0 & 0 & 1 & 0 \\
\hline 27. & South Carolina & 8 & 6 & 2 & 0 & 0 & 0 & 0 & 0 & 0 \\
\hline 28. & Texas & 5 & 2 & 2 & 1 & 0 & 0 & 0 & 0 & 0 \\
\hline 29. & Toledo (OBES) & 5 & 2 & 1 & 0 & 0 & 1 & 0 & 0 & 1 \\
\hline 30. & Toledo (UT) & 5 & 2 & 1 & 2 & 0 & 0 & 0 & 0 & 0 \\
\hline 31. & Wisconsin & 6 & 4 & 2 & 0 & 0 & 0 & 0 & 0 & 0 \\
\hline \multicolumn{3}{|c|}{ DISTRIBUTION } & $44 \%$ & $20 \%$ & $4 \%$ & $8 \%$ & $17 \%$ & $.5 \%$ & $2 \%$ & $5 \%$ \\
\hline
\end{tabular}


National financial indicators (NFIN) are underrepresented in the regional models, accounting for only 2 percent of all the components listed in Table 1. This underrepresentation contrasts with the importance assigned to monetary phenomena in the theoretical and empirical literature. In a business cycle context, monetary growth slows down in the later stages of cyclical expansions and inflationary pressure increases. The typical result is a decline in the constant-dollar value of the money stock (M2 in 1982 dollars) which Koch and Rasche (1988) found to possess a high degree of economic significance in the national index of leading indicators published by the U.S. Department of Commerce. Although regions react differently, monetary restrictions may produce slowdowns or contractions in regional production, income, and employment. Beare (1976) and Kozlowski (1989) found significant leading behavior for measures of the national money stock with respect to regional income and employment. Integrating the constant-dollar value of the money stock (M2) into regional models may capture early symptoms of cyclical changes that may affect regions later through links to fixed investment, inventory accumulation, and expenditures on consumer durable products.

In Table 2 the components, as well as cross correlations with employment, are given for four models: Detroit, South Carolina, Toledo, and Wisconsin. These models were examined because of the availability of data from source agencies covering a relatively long period during which several cyclical contractions and expansions occurred. Cross correlations with lags up to 12 months (four quarters for Toledo) are higher for M2 than for nearly all of the other components. This result is most striking in comparison to regional labor market indicators, which account for 75 percent of the components for the South Carolina index, 57 percent for Wisconsin, 40 percent for Toledo, and 33 percent for Detroit. In a bivariate sense, the national monetary variable outperforms the regional series with respect to leads in nearly all cases examined. Therefore, the deflated value of M2 appears to be a strong candidate to include in regional models.

\section{INTEGRATING MONEY INTO REGIONAL INDEXES}

The four models were reconstructed as weighted averages of the set of time series as given in Equation (3), with M2 added as a component:

$$
I L I_{t}=\sum_{n} w_{i} C_{i, t}
$$

where $\mathrm{n}=$ number of time series; 
TABLE 2

Cross Correlations: Model Components and M2 with Employment

\begin{tabular}{|c|c|c|c|c|}
\hline \multirow[b]{2}{*}{ Detroit: monthly series } & \multicolumn{4}{|c|}{ Lead times - months } \\
\hline & $(-3)$ & $(-6)$ & $(-9)$ & $(-12)$ \\
\hline $\begin{array}{l}\text { Average workweek in manufacturing } \\
\text { Initial claims for unemployment insurance } \\
\text { New residential building permits } \\
\text { Consumer installment loans-Detroit banks } \\
\text { Index of consumer sentiment-University of Michigan } \\
\text { U.S. dealers' day's supply of new cars } \\
\text { M2 (1982 dollars) }\end{array}$ & $\begin{array}{r}.318 \\
-.258 \\
.259 \\
.890 \\
.302 \\
.293 \\
.757\end{array}$ & $\begin{array}{r}.197 \\
-.158 \\
.208 \\
.832 \\
.204 \\
.366 \\
.678\end{array}$ & $\begin{array}{r}.110 \\
-.075 \\
.155 \\
.760 \\
.136 \\
-.392 \\
.600\end{array}$ & $\begin{array}{r}.040 \\
.002 \\
.099 \\
.681 \\
.066 \\
-.380 \\
.526\end{array}$ \\
\hline \multicolumn{5}{|l|}{ South Carolina: monthly series } \\
\hline $\begin{array}{l}\text { Average workweek in manufacturing } \\
\text { Initial claims for unemployment insurance } \\
\text { Nonfarm job openings unfilled } \\
\text { Total unemployment rate } \\
\text { Ratio of average weeks claimed } \\
\text { to insured employment } \\
\text { Unemployment insurance benefits } \\
\text { New residential building permits } \\
\text { New business incorporations } \\
\text { M2 (1982 dollars) }\end{array}$ & $\begin{array}{r}.305 \\
.220 \\
.369 \\
-.134 \\
\\
-.345 \\
.239 \\
-.321 \\
.876 \\
.857\end{array}$ & $\begin{array}{r}.285 \\
.224 \\
.341 \\
-.125 \\
\\
-.306 \\
.247 \\
-.303 \\
.829 \\
.806\end{array}$ & $\begin{array}{r}.285 \\
.217 \\
.339 \\
-.118 \\
\\
-.282 \\
.247 \\
-.262 \\
.788 \\
.760\end{array}$ & $\begin{array}{r}.289 \\
.202 \\
.364 \\
-.115 \\
\\
-.274 \\
.236 \\
-.201 \\
.752 \\
.719\end{array}$ \\
\hline \multicolumn{5}{|l|}{ Wisconsin: monthly series } \\
\hline $\begin{array}{l}\text { Average workweek in manufacturing } \\
\text { Initial claims for unemployment insurance } \\
\text { Job openings } \\
\text { Overtime hours in manufacturing } \\
\text { Gain in phone access lines } \\
\text { Business plans examined, including alterations } \\
\text { New business incorporations } \\
\text { M2 (1982 dollars) }\end{array}$ & $\begin{array}{r}.177 \\
.115 \\
-.205 \\
.733 \\
.191 \\
.445 \\
.683 \\
.792\end{array}$ & $\begin{array}{r}.147 \\
.137 \\
-.253 \\
.639 \\
.181 \\
.346 \\
.647 \\
.735\end{array}$ & $\begin{array}{r}.128 \\
.153 \\
-.295 \\
.562 \\
.168 \\
.304 \\
.600 \\
.681\end{array}$ & $\begin{array}{r}.113 \\
.157 \\
-.305 \\
.489 \\
.150 \\
.239 \\
.548 \\
.634\end{array}$ \\
\hline & \multicolumn{4}{|c|}{ Lead times - quarters } \\
\hline Toledo: quarterly series & $(-1)$ & $(-2)$ & $(-3)$ & $(-4)$ \\
\hline $\begin{array}{l}\text { Average workweek in manufacturing } \\
\text { Initial claims for unemployment insurance } \\
\text { New residential building permits } \\
\text { Total deposits (1982 dollars)-Toledo Banks } \\
\text { Change in credit outstanding-Toledo Banks } \\
\text { M2 (1982 dollars) }\end{array}$ & $\begin{array}{r}.324 \\
-.296 \\
-.042 \\
.824 \\
-.086 \\
.734\end{array}$ & $\begin{array}{r}.213 \\
-.224 \\
-0.38 \\
.753 \\
-.154 \\
.642\end{array}$ & $\begin{array}{r}.123 \\
-.167 \\
-0.25 \\
.681 \\
-.212 \\
.551\end{array}$ & $\begin{array}{r}.061 \\
-.092 \\
-.006 \\
.611 \\
-.263 \\
.466\end{array}$ \\
\hline
\end{tabular}

Note: Cross correlations for 1972-1989. Toledo series cover 1976:1-1989:4; for Wisconsin overtime hours, 1979:1-1989:12, and phone access lines, 1976:1-1989:12. 
$w_{i}=$ weight of the ith series;

$\mathrm{C}_{\mathrm{i}, \mathrm{t}}=$ value of the ith series at time $\mathrm{t}$ (month or quarter).

Performance of the models with the original components, ILI(n), was compared to the revised model, $\mathrm{ILI}(\mathrm{n}+1)$, with respect to turning points, volatility, false signals, and quantitative forecasts.

Estimates of volatility not attributable to seasonal, cyclical, and trend movements were considerably less for ILI(n+1), as shown in Table 3 . The decrease in nonsystematic fluctuations when M2 was added to the model was greatest for Detroit, with the estimate for $\mathrm{ILI}(n+1)$ over the entire period being only 41 percent of that for ILI(n). The lower degree of volatility makes the revised indexes with M2 smoother and represents a positive improvement in a short-run cyclical forecasting environment.

TABLE 3

Estimates of Irregular Movements for Indexes*

\begin{tabular}{lrr}
\hline \hline & $\mathbb{L I}(\mathrm{n})$ & \multicolumn{1}{c}{$\mathrm{LI}(\mathrm{n}+1)$} \\
\hline Detroit & .03150 & .01304 \\
South Carolina & .06997 & $.03 \mathrm{w} 394$ \\
Toledo & .01900 & .00970 \\
Wisconsin & .01833 & .01086 \\
\hline
\end{tabular}

*Ratio of the standard deviation to the mean of the irregular movements.

Figures 1 and 2 show cyclical turning points for each model. Leading behavior is evident for ILI(n) and ILI(n+1) compared to peaks and troughs in employment. This lead timing for the indexes was nearly unchanged when M2 was added as a component. Two positive changes are notable, however. ILI(9) for South Carolina exhibits a slightly longer lead than ILI(8) at the trough in 1982, and for Wisconsin, ILI(8) leads by more months than ILI(7) prior to that state's employment contraction in 1980.

False signals of cyclical turning points are major forecasting errors for indexes designed to predict changes in cyclical phases of regional economic activity. This is especially the case for forecasts of impending recessions. False signals of contractions occurred in 1987 for Detroit, and in 1976, 1984, and 1985 for South Carolina. Figure 2 shows a similar occurrence in 1984-85 for the Wisconsin index. No cyclical contractions occurred in employment during those 
FIGURE 1

Index and Employment: Detroit and South Carolina

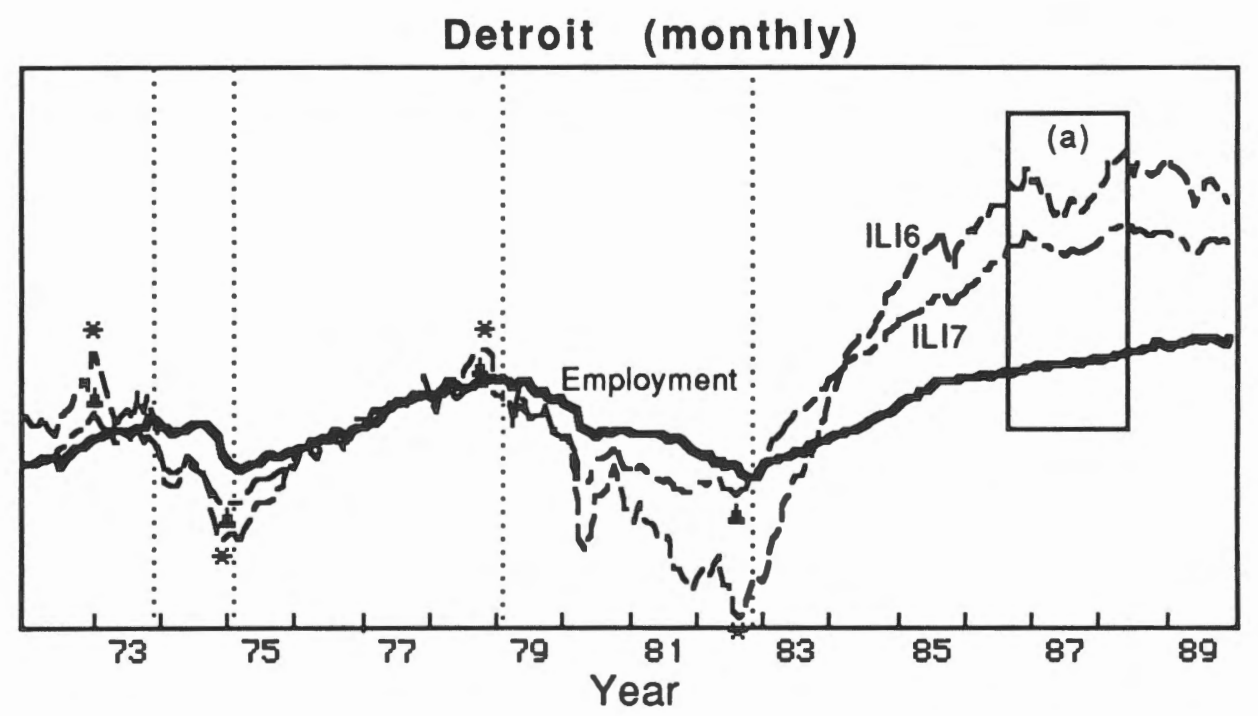

South Carolina (monthly)

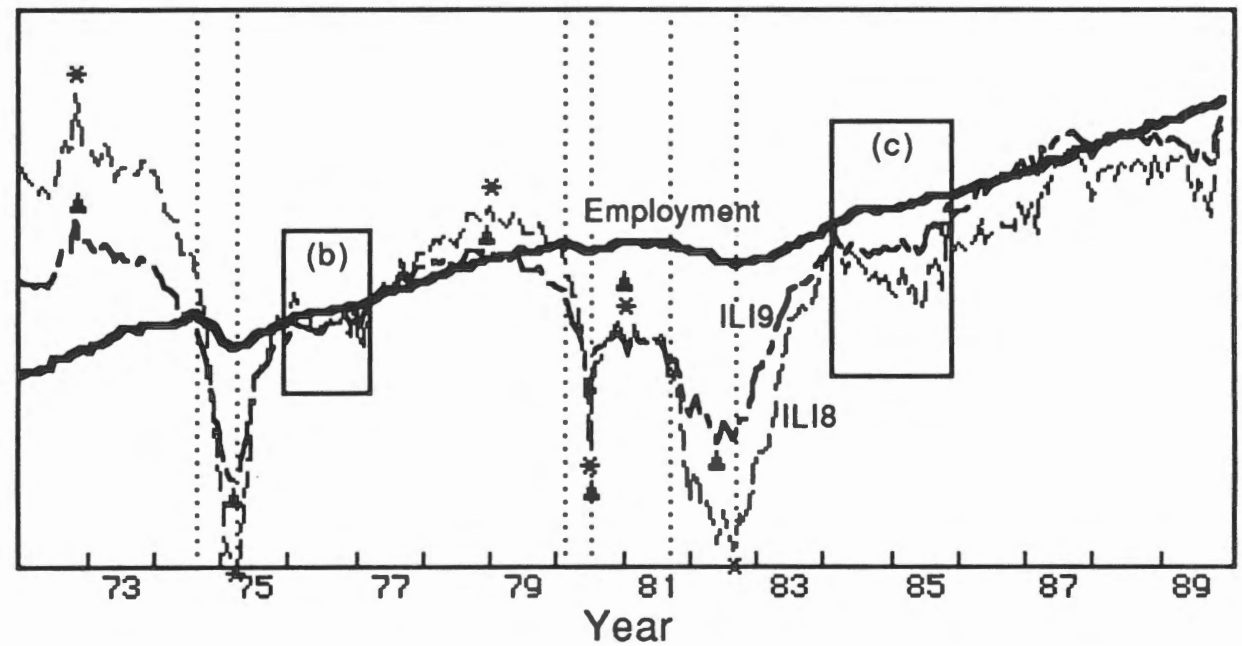

Notes: a) Vertical dashed lines mark cyclical peaks and troughs in employment.

b) * indicates turning point in $\mathrm{ILI}(n)$; $\boldsymbol{\alpha}$ indicates turning point in $\mathrm{ILI}(n+1)$.

c) (a), (b), and (c) indicate "false signals." 
FIGURE 2

Index and Employment: Toledo and Wisconsin

\section{Toledo (quarterly)}
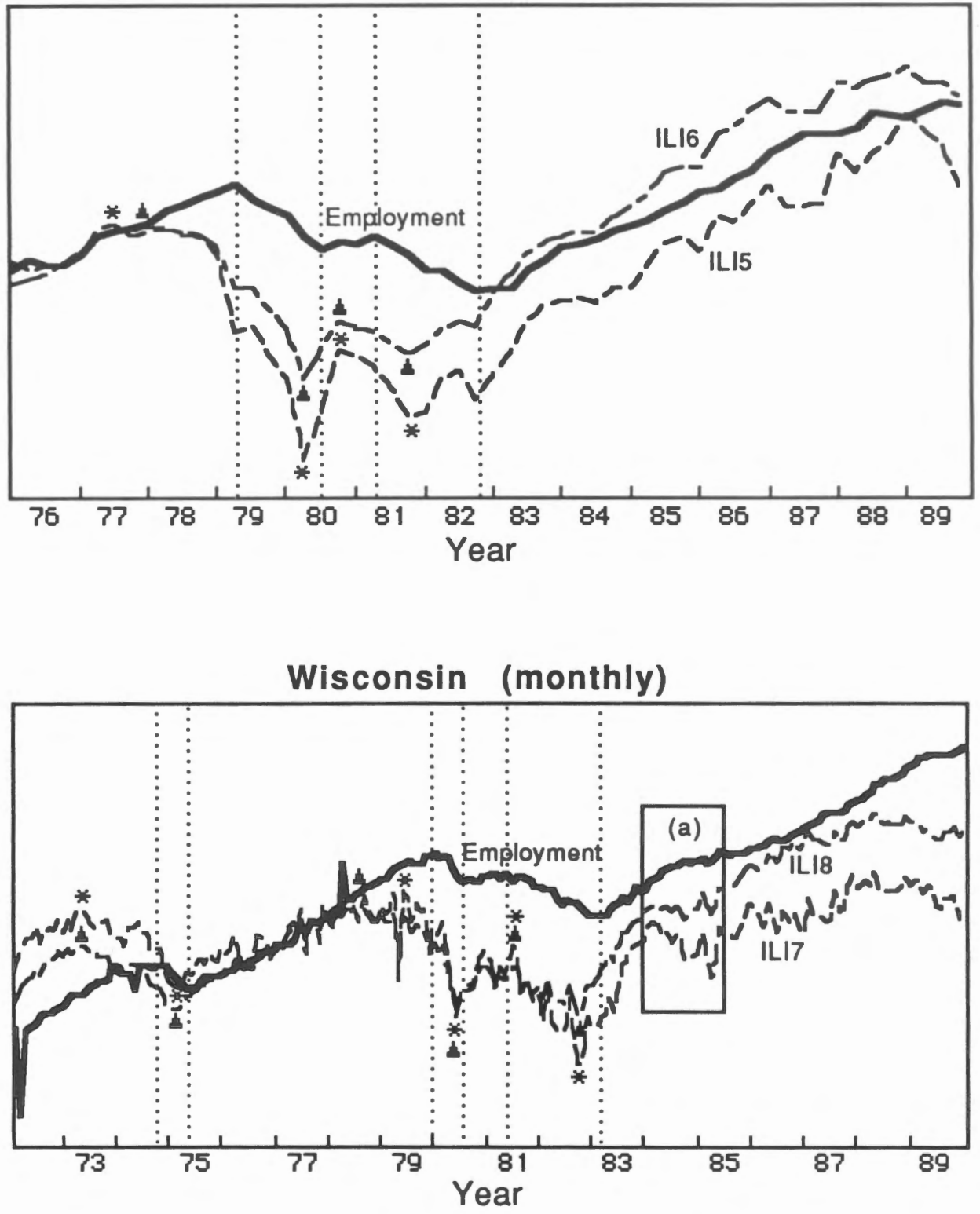

Notes: a) Vertical dashed lines mark cyclical peaks and troughs in employment. b) * indicates turning point in $I L I(n) ; ~ \&$ indicates turning point in $\mathrm{ILI}(n+1)$. c) (a) indicates "false signal." 
periods. For Detroit, ILI(6) fell 6.1 percent over seven months in 1987, but the drop in ILI(7) was only 2.8 percent. For South Carolina ILI(8) declined 9.3 percent over ten months in 1976 and dropped 15 percent over fifteen months in 1984-85, compared to a falloff of just 2.4 percent over four months and 3.8 percent over six months for ILI(9) during the two periods. The behavior of ILI( 8 ) for Wisconsin was more impressive, because it declined only 1.6 percent over a sixmonth period in 1984-85 compared to a drop of 7.3 percent over thirteen months for ILI(7). In each case, false signals were reduced when M2 was added to the models. In two cases, South Carolina (b) and Wisconsin (a), the slight declines remaining in ILI $(n+1)$ were more in the order of short, random fluctuations than cyclical contractions.

The 1984-85 episode illustrates a problem with regional indexes dominated heavily by regional labor market processes. The false signal for ILI(8) in South Carolina is attributable to contractions in six regional labor market indicators out of the eight components listed in Table 2. Regional investment indicators, new building permits for residential housing, and new business incorporations did not decline during this period; neither did M2.

Quantitative forecasts of employment were also tested by using a specification given in Equation (4):

$$
\begin{aligned}
& \mathrm{EMP}_{\mathrm{t}}=\alpha+\beta_{\mathrm{i}}\left(\mathrm{ILI}_{\mathrm{t}-\mathrm{j}}\right)+\delta \mathrm{T}+\varepsilon \\
& \text { where } \mathrm{EMP}_{\mathrm{t}}=\text { employment; } \\
& \mathrm{ILI}_{\mathrm{t}-\mathrm{j}}=\text { index of leading indicators with lag } \mathrm{t}-\mathrm{j} ; \\
& \mathrm{T}=\text { trend. }
\end{aligned}
$$

Estimates over the entire sample period are reported in Table 4. Significant lags vary somewhat for ILI(n) and ILI(n+1); but overall there is little difference between these estimates. The estimates do reveal the leading behavior of the indexes over the entire period, reinforcing the turning point and cross-correlation results cited above.

Ex-post forecast evaluation was done using estimates of Equation (4) for sample periods 1979 and 1987, and then predicting employment in two out-ofsample periods: one during the 1980-81 recession, another during the later stage of the 1988-89 expansion. This evaluation covered 24 months for Detroit, South Carolina, and Wisconsin, and eight quarters for Toledo in each forecast period. No adjustments were made to the in-sample estimates during the forecast period.

Table 5 shows the improvement in the mean absolute percent error (MAPE) and the root mean square error (RMSE) using ILI(n+1). Reductions in MAPE and RMSE are sizable in nearly all cases, especially during recession years. During that period, MAPE decreased 40 percent for Detroit, 21 percent for South 
TABLE 4

Regression Estimates: Employment and Indexes of Leading Indicators

Detroit (sample period: 1972-1989)

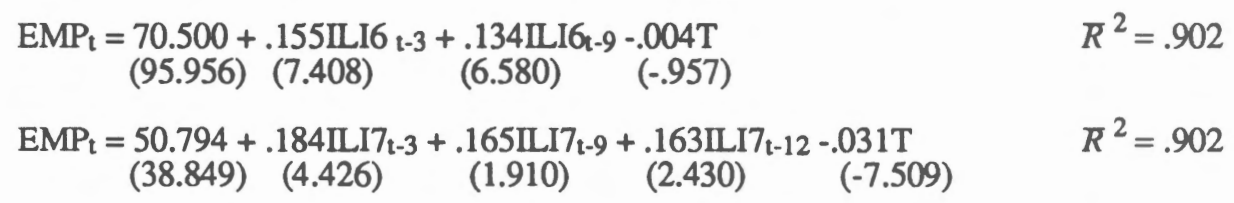

South Carolina (sample period: 1972-1989)
$\mathrm{EMP}_{\mathrm{t}}=66.538+.099 \mathrm{ILI} \mathrm{f}_{\mathrm{t}-2}+.027 \mathrm{ILI} 8_{\mathrm{t}-6}+.025 \mathrm{ILI} 8_{\mathrm{t}-12}+.020 \mathrm{ILI} 8_{\mathrm{t}-18}$
$\begin{array}{llll}(94.625) & (10.155) & (2.290) & (2.498)\end{array}$
$+.019 \mathrm{ILI} 8_{\mathrm{t}-24}+.221 \mathrm{~T}$
$(2.561) \quad(105.09)$
$R^{2}=.988$
$\mathrm{EMP}_{\mathrm{t}}=62.472+.105 \operatorname{ILI}_{\mathrm{t}-2}+.051 \mathrm{ILI} \mathrm{t}_{\mathrm{t}-6}+.048 \mathrm{ILI}_{\mathrm{t}-12}+.059$ ILI9 $_{\mathrm{t}-24}$
$\begin{array}{llll}(68.925) & (5.457) \quad(2.071) & (2.984) & (5.900)\end{array}$
$+.189 \mathrm{~T}$
(63.95)

$$
R^{2}=.986
$$

Toledo (sample period: $1976-1989$ )

$$
\begin{aligned}
& \mathrm{EMP}_{\mathrm{t}}=32.545+.271 \mathrm{ILI}_{\mathrm{t}-1}+.152 \mathrm{ILI} 5_{\mathrm{t}-4}+.093 \mathrm{ILI}_{\mathrm{t}-6}+.110 \mathrm{ILI} 5_{\mathrm{t}-10} \\
& (14.400)(6.914) \quad(3.607) \quad(2.206) \quad(2.607) \\
& +.102 \mathrm{ILI} 5_{\mathrm{t}-12}+.090 \mathrm{~T} \\
& (2.754) \quad(4.015) \\
& R^{2}=.977
\end{aligned}
$$

$\mathrm{EMP}_{\mathrm{t}}=23.509+.424 \mathrm{ILI}_{\mathrm{t}-2}+.137 \mathrm{ILI} \mathrm{t}_{\mathrm{t}-4}+.178 \mathrm{ILI}_{\mathrm{t}-10}+.103 \mathrm{ILI}_{\mathrm{t}-12}$
(10.973) (8.137)
(2.571)
(3.280)
$(2.151)$

\section{Wisconsin (sample period: 1972-1989)}

$$
\begin{aligned}
& \mathrm{EMP}_{\mathrm{t}}=25.049+.180 \mathrm{ILI}_{\mathrm{t}-3}+.182 \mathrm{ILI}_{\mathrm{t}-6}+.185 \mathrm{ILI}_{\mathrm{t}-15}+.131 \mathrm{ILI}_{\mathrm{t}-24} \\
& \begin{array}{lll}
(6.857)(3.429) \quad(3.173) & (4.370) & (3.499)
\end{array} \\
& +.129 \mathrm{~T} \\
& \text { (45.632) } \\
& R^{2}=.943 \\
& \mathrm{EMP}_{\mathrm{t}}=38.875+.312 \mathrm{ILI} 8 \mathrm{t}-9+.266 \mathrm{ILI} 8_{\mathrm{t}-24}+.088 \mathrm{~T} \\
& \begin{array}{lll}
(12.190)(7.948) \quad(6.498) & (20.091)
\end{array} \\
& R^{2}=.932
\end{aligned}
$$

Note: $\mathrm{t}$-values in parentheses. 
TABLE 5

Ex-post Forecast Errors for Leading Indicator Models

\begin{tabular}{lcccc}
\hline \hline Area & $\begin{array}{c}\text { Forecast } \\
\text { Period }\end{array}$ & Index & $\begin{array}{c}\text { Mean Absolute } \\
\text { Percent Emor }\end{array}$ & $\begin{array}{c}\text { Root Mean } \\
\text { Square Error }\end{array}$ \\
\hline Detroit & $1980: 1-$ & ILI6 & 3.893 & 3.889 \\
& $1981: 12$ & ILI7 & 2.219 & 2.434 \\
& $1988: 1-$ & ILI6 & 1.084 & 1.436 \\
South & $1989: 12$ & ILI7 & 0.801 & 1.129 \\
Carolina & $1980: 1-$ & ILI8 & 0.950 & 1.351 \\
& $1981: 12$ & ILI9 & 0.752 & 0.996 \\
& $1988: 1-$ & ILI8 & 2.167 & 3.335 \\
Toledo & $1989: 12$ & ILI9 & 1.878 & 3.009 \\
& $1981: 1-$ & ILI5 & 5.174 & 5.808 \\
& $1982: 4 *$ & ILI6 & 2.768 & 2.901 \\
& $1988: 1-$ & ILI5 & 1.898 & 2.471 \\
& $1989: 4$ & ILI6 & 0.664 & 0.890 \\
Wisconsin & $1980: 1-$ & ILI7 & 1.472 & 1.884 \\
& $1981: 12$ & ILI8 & 1.016 & 1.375 \\
& & & & 0.985 \\
& $1988: 1-$ & ILI7 & 0.676 & 0.951 \\
& $1989: 12$ & ILI8 & 0.646 & \\
\hline
\end{tabular}

* Forecast begins in 1981 instead of 1980 and lags in the model restricted to four instead of the 12 quarters from Table 4 because of the lack of data before 1976.

that period, MAPE decreased 40 percent for Detroit, 21 percent for South Carolina, 47 percent for Toledo, and 31 percent for Wisconsin when ILI $(n+1)$ was used instead of ILI(n) forecast employment.

\section{CONCLUSIONS}

The results for the four models examined are encouraging. Combining the national money stock with regional variables that comprise a sizable share of the leading indicator models contributed to improved forecasting performance in each of the cases examined. Integrating this monetary indicator into leading indicator models appears to be empirically promising as well as conceptually sound. In addition, the results point in a direction that needs to be explored when such models are being constructed. Accounting for national monetary changes in the regional 
narrow; and this procedure may contribute significantly to the information content imbedded in this class of models.

\section{REFERENCES}

Abdullah, D., and P. Rangazas. "Money and the Business Cycle: Another Look." Review of Economics and Statistics 70 (1988): 680-685.

Allen, L. "Regional Economic Stabilization and the Acceleration Principle." Growth and Change 13 (1982): 10-17.

Beare, J. "A Monetarist Model of Regional Business Cycles." Journal of Regional Science 16 (1976): 57-63.

Carlstrom, C., and E. Gamber. "Why We Don't Know Whether Money Causes Output." Economic Review-Federal Reserve Bank of Cleveland 25 (1989): 27-39.

Cohen, J., and A. Maeshiro. "The Significance of Money on the State Level." Journal of Money, Credit, and Banking 9 (1977): 672-678.

Detroit Edison. Detroit Area Quarterly Economic Trends. Detroit: Detroit Edison, 1990

Friedman, B. "Money, Credit, and Interest Rates in the Business Cycle." In The American Business Cycle, pp. 395-438. Edited by Robert J. Gordon. Chicago: University of Chicago Press, 1986.

Hymans, S., J. Crary, and J. Wolfe. "The U.S. Economic Outlook for 1990-91." University of Michigan Research Seminar in Quantitative Economics, March 1990.

Koch, P., and R. Rasche. "An Examination of the Commerce Department Leading-Indicator Approach." Journal of Business and Economic Statistics 6 (1988): 167-187.

Kozlowski, P. J. "Forecasting With Leading Indicators: Regional Economic Sense or Nonsense?" Regional Science Perspectives 19 (1989): 3-24.

Meltzer, A. "Comments on Money, Credit, and Interest Rates in the Business Cycle." In The American Business Cycle, pp. 441-450. Edited by Robert J. Gordon. Chicago: University of Chicago Press, 1986.

Roberts, R., and H. Fishkind. "The Role of Monetary Forces in Regional Economic Activity: An Econometric Simulation Analysis." Journal of Regional Science 19 (1979): 15-29.

University of South Carolina and the South Carolina Employment Security Commission. South Carolina Economic Indicators. Columbia, SC: College of Business Administration, University of South Carolina, 1990. 
Wisconsin Department of Industry, Labor and Human Relations. Wisconsin Employment and Economic Indicators. Madison, Wis.: Department of Industry, Labor, and Human Relations, 1990.

Zarnowitz, V. "Recent Work on Business Cycles in Historical Perspective: A Review of Theories and Evidence." Journal of Economic Literature XXIII (1985): 523-580. 